\title{
MODELING AS A METHOD FOR SCIENTIFIC COGNITION OF COMPLEX MEAT SYSTEMS
}

\section{МОДЕЛИРОВАНИЕ КАК МЕТОД НАУЧНОГО ПОЗНАНИЯ СЛОЖНЫХ МЯСНЫХ СИСТЕМ}

Nikitina M.A., Zakharov A.N., Nasonova V.V., Lisitsyn A.B.

V.M. Gorbatov Federal Research Center for Food Systems of Russian Academy of Sciences, Moscow, Russia

Ключевые слова: компьютерное моделирование, статистическая обработка, система SSS Biо, экспериментальные данные, мясной фарш, изил моделируемой системы.

\section{Аннотация}

В статье рассмотрены вопросы, связанные с интеграиией знаний «технология мясных продуктов + компьютеры + математические методы». Показаны возможности использования компьютерной системы и математических методов для оптимального решения задач в области пищевой биотехнологии и технологии мясных продуктов.

Разработана и описана прикладная программа SSS Bio, реализованная в компьютерной системе. При помощи однофакторного дисперсионного анализа, являющегося одним из модулей системы, получены исчерпывающее количество статистических данных для интерпретации результатов. Модули программы (корреляциионный и регрессионный анализ) позволяют установить структуру и параметры модели, связывающей количественные результируюшую и факторные переменные, и оценить степень ее согласованности с экспериментальными данными. Этот вид статистического анализа позволяет решать главную задачу эксперимента в случае, если наблюдаемые и результирующие переменные являются количественными.

На основе экспериментальных данных при помощи компьютерной системы SSS Biо рассчитаны математические модели влагосвязывающей (ВСС), влагоудерживающей (ВУС) и жиросвязывающей (ЖСС) способностей в фарше для колбасных изделий с использованием соевого изолированного белка в зависимости от содержания жира и белка с использованием модуля множественной регрессии компьютерной системы.

Полученная стохастическая зависимость изменения ВСС (Y) от содержания общего белка (Х1) и жира (Х2) в колбасном фарше показывает, что при постоянном уровне жира увеличение общего содержания белка способствует росту ВСС фарша. Однако рост ВСС на единииу белка уменьшается с увеличением количества жира.
\end{abstract}

\section{Введение}

Мясной фарш является сложной системой, образуемой в результате интенсивного механического измельчения тканей с последующим перемешиванием с добавлением пищевых ингредиентов. Получаемая дисперсная система состоит из дисперсионной среды - гидратированных белковых мицелл и жировых частиц различных размеров и из дисперсионной среды - раствора белков и низкомолекулярных веществ. В мясной эмульсии белок и вода образуют матрицу,
Keywords: computer modeling, statistical processing, SSS Bio system, experimental data, sausage meat, cycle of modeling system.

\section{Abstract}

The paper examines the issues associated with the integration of knowledge in meat product technology + computers + mathematical methods. The possibilities to use a computer system and mathematical methods for an optimal solution to tasks in the field of food biotechnology and meat product technology are demonstrated. The applied software program SSS Bio realized in the computer system was developed and described. Using the one-way analysis of variance, which is one of the system modules, a comprehensive amount of statistical data for interpretation of the results was obtained. The program modules (correlation and regression analysis) allow establishing the model structure and parameters that link quantitative resulting and factorial variables, as well as assessing a degree of their correspondence with the experimental data. This kind of statistical analysis makes it possible to solve the main task of an experiment when the observed and resulting variables are quantitative.

Based on the experimental data obtained with the use of the computer system SSS Bio, the mathematical models of moisture binding capacity (MBC), moisture holding capacity (MHC) and fat binding capacity (FBC) in sausage meat were calculated for sausages with isolated soya protein depending on the fat and protein content using the module of multiple regression of the computer system. The obtained stochastic dependence of changes in $M B C(Y)$ on the total protein (X1) and fat (X2) content in sausage meat shows that at the constant level of fat, an increase in total protein favors a growth in $M B C$ of sausage meat. However, a growth in $M B C$ per unit of protein decreases with an increase in the fat amount.

\section{Introduction}

Sausage meat is a complex system, developed as a result of mechanical mincing of tissues followed by mixing with added food ingredients. The obtained dispersion system consists of a dispersed phase (hydrated protein micelles and fat particles of different sizes) and a dispersion medium (a protein solution and low molecular weight substances). In a meat emulsion, protein and water create a 
которая окружает жир, т.е. иначе говоря, сырой колбасный фарш - это эмульсия жира в воде, при этом солерастворимые белки являются стабилизаторами эмульсии [1].

Подобного рода мясные эмульсии относят к коагуляционным структурам, частицы которых связаны силами межмолекулярного взаимодействия в единую пространственную сетку (каркас).

При последующем термическом воздействии в результате взаимодействия денатурирующих белков возникает пространственный каркас - термотропный гель, прочность которого зависит от количества и степени взаимодействия микрофибриллярных белков.

Под моделированием [2] понимается процесс построения, изучения и применения моделей. Оно тесно связано с такими категориями, как абстракция, аналогия, гипотеза и др. Процесс моделирования обязательно включает и построение абстракций, и умозаключения по аналогии, и конструирование научных гипотез. Главная особенность моделирования в том, что это метод опосредованного познания с помощью объектов-заменителей.

Моделирование - одно из фундаментальных понятий теории информации, на которой базируется любой метод научного исследования (познания). В своих знаменитых рассуждениях Аристотель (первая книга «Метафизика» [3]) о «эпистеме» (знание, наука) и «технэ» (технологии, искусства)) определяет некоторые ключевые отличия, которые часто цитируются и даже используются для анализа современной науки и техники.

Однако никакого отличия, по существу, между ними нет: «эпистеме» и «технэ» познают общее через причины, но социальное различие между ними имеется. Оказывается, науки, по Аристотелю, не служат никакой пользе общества, а технологии служат. Технологии существуют ради какой-либо выгоды или пользы, наука же существует ради себя самой, знание ради знания: из наук большей мудростью обладает та, которая желательна ради нее самой, нежели та, которая желательна ради извлекаемой из нее пользы. В остальном «технология» не отличается от науки: она поднимается над обычными показаниями чувств, предполагает знание причин и общего, способно научить. Можно сказать, что «технэ» - это «эпистеме» в ее практическом применении.

Современная парадигма науки и технологий (Рис. 1) гораздо сложнее и разнообразнее, чем во времена Аристотеля [4-6].

В настоящее время применительно к техническим наукам различают следующие виды моделирования:

- кониептуальное моделирование, при котором совокупность уже известных фактов или представлений относительно исследуемого объекта или системы интерпретируется с помощью некоторых специальных знаков, символов, операций над ними или с помощью естественного или искусственных языков; matrix, which surrounds fat; that is, in other words, raw sausage meat is an emulsion of fat in water; with that, salt soluble proteins are emulsion stabilizers [1].

This kind of meat emulsions are assigned to coagulation structures, which particles are connected in the united spatial net (framework) by the forces of intermolecular interactions.

As a result of the interaction of denaturing proteins during the following thermal treatment, a spatial framework, a thermotropic gel, is formed, which strength depends on an amount and degree of microfibrillar protein interaction.

By the term modeling [2], a process of building, studying and using models is meant. It is closely related with such categories as an abstraction, analogue, hypothesis and so on. The modeling process necessarily includes creation of abstractions, inference by analogy and construction of scientific hypotheses. The main peculiarity of modeling is the fact that it is a method of mediated perception by substitute objects.

Modeling is one of the fundamental concepts of the information theory, on which any method of scientific investigation (cognition) is based. In his famous writings, Aristotle (the first book Metaphysics [3]) about epistêmê (knowledge, science) and technê (technologies, art)) determines several key differences, which are often cited and even used for analysis of the modern science and technology.

However, virtually, there is no any difference between them: both epistêmê and technê cognize general through causes; but, there are social differences between them. It appears that sciences, according to Aristotle, do not serve for the benefit of the society, while technologies do. Technologies exist for the sake of a profit or benefit; a science exists for the sake of itself - knowledge for the sake of knowledge. Among sciences, more wisdom has the one that is desirable for the sake of itself than the one that is desirable for the sake of an obtained benefit. As for the rest, technology does not differ from science: it rises over general evidence of the senses, assumes the knowledge of causes and general, and is able to teach. It can be said that technê is epistêmê in its practical use.

The modern paradigm of science and technology (Fig. 1) is much more complex and diverse than in the time of Aristotle [4-6].

At present, with regard to technical sciences, several kinds of modeling are distinguished:

- conceptual modeling, in which a complex of already known factors or insights about an object under investigation or a system are interpreted by several special characters, symbols, operations with them or by natural or artificial languages; 
- бизическое моделирование, при котором модель и моделируемый объект представляет собой реальные объекты или процессы единой, или различной физической природы, причем между процессами в объекте-оригинале и в модели выполняются некоторые соотношения подобия, вытекающие из схожести физических явлений;

- структурно-функииональное моделирование, при котором моделями являются схемы (блок-схемы), графики, чертежи, диаграммы, таблицы, рисунки, дополненные специальными правилами их объединения и преобразования;

- математическое (логико-математическое) модетирование, при котором моделировании, включая построение модели, осуществляется средствами математики и логики;

- имитационное (программное) моделирование, при котором логико-математическая модель исследуемого объекта представляет собой алгоритм функционирования объекта, реализованный в виде программного комплекса для компьютера.

Перечисленные виды моделирования могут применяться при исследовании сложных объектов, как самостоятельно, так и одновременно, либо в некоторой комбинации.

Математическое моделирование включает две основные стадии - составление математической модели и ее исследование.

При математическом моделировании выполнение одного из основных этапов - построение математических моделей по экспериментальным данным - в настоящее время просто немыслимо без современной вычислительной техники. Компьютер должен выполнять роль вспомогательного средства для решения задач, решаемых обычными вычислительными средствами, алгоритмами, технологиями; роль средства постановки и решения новых задач, не решаемых традиционными средствами, алгоритмами, технологиями
- physical modeling, in which a model and modeling object are real objects or processes of the common or different physical nature; with that, several similarity relations resulting from a similarity in physical phenomena are executed between the processes in an original object and in a model;

- structural-functional modeling, in which models are charts (flow charts), graphs, diagram, tables, figures with added special rules for their combination and transformation;

- mathematical (logico- mathematical) modeling, in which modeling, including construction of a model, is carried out by means of mathematics and logic.

- simulation (program) modeling, in which a logicomathematical model of an object under investigation is an algorithm of object functioning realized in a form of a computer program complex;

The listed types of modeling can be applied when studying complex objects both individually and simultaneously or in some combinations.

Mathematical modeling includes two main stages: creation of a mathematical model and its investigation.

Nowadays, execution of one of the main stages (construction of mathematical models by experimental data) in mathematical modeling is absolutely unthinkable without modern computation technique. A computer has to play a role of an auxiliary means for solving tasks that are solved by usual methods, algorithms, technologies; a role of a means for setting and solving new tasks that cannot be solved by traditional methods, algorithms, technologies

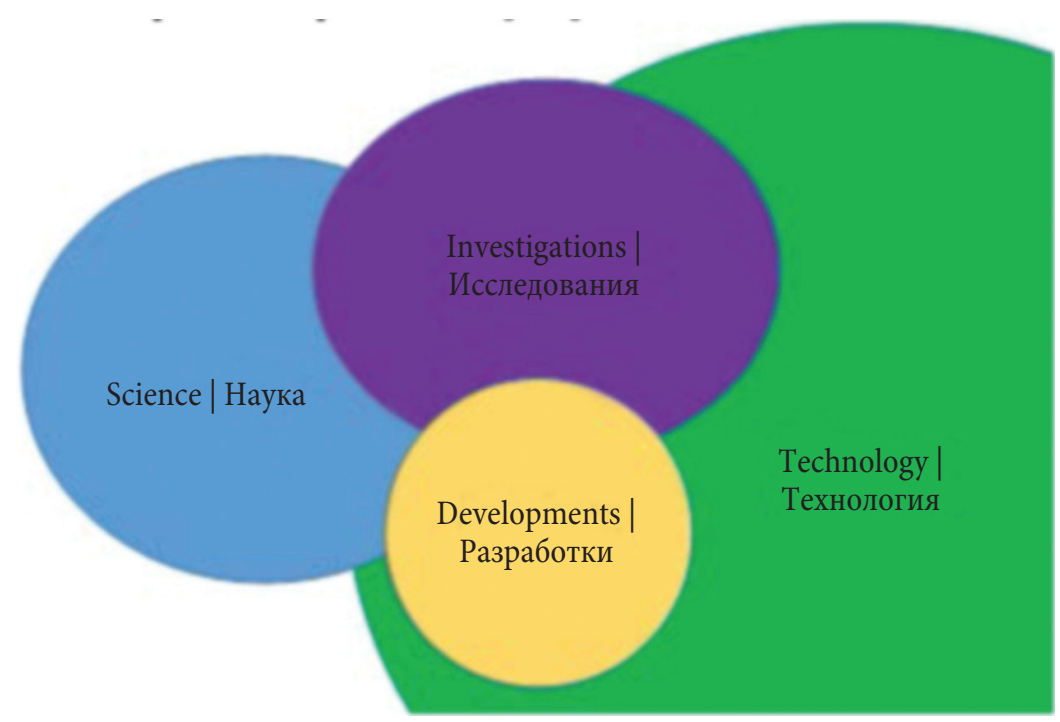

Fig. 1. Relationships between science, investigations, developments and technologies

Рис. 1. Отношения между наукой, исследованиями, разработками и технологиями 
(аппарат нечеткой логики, роевые, генетические алгоритмы); роль средства конструирования компьютерных обучающе-моделирующих сред (мультиагентное моделирование).

Перспективы развития мясоперерабатывающей промышленности во многом зависят от эффективности научных исследований в области прикладной биотехнологии и внедрением их результатов в производство. При решении задач управления научными исследованиями необходимо оценивать их перспективность, определять вклад отдельных разработок в решении поставленных проблем, разрабатывать стратегию внедрения полученных результатов. В связи со сложностью и глубиной перечисленных проблем для их разрешения требуются специалисты, обладающие знаниями по конкретным технологиям переработки мясного сырья и умеющие использовать средства вычислительной техники.

Большинство разработанных автоматизированных и компьютерных пакетов прикладных программ для обработки экспериментальных исследований с привлечением статистических методов (Statistica, SPSS Statistical Package for Social Science, MatLab, MathCad, MuMath, Statgraf, Пакет анализа в MS Excel и др.) информационно и методологически независимы от последующих технологических расчетов и проектных разработок. Обзор универсальных статистических пакетов по одному из важнейших показателей - функциональности - представлен в работе [7].

Для коммерциализации и ускорения внедрения научно-исследовательских разработок в производство, перспективным является объединение знаний в области математического моделирования, информационных технологий и технологии в компьютерной системе планирования эксперимента с подсистемой технологического расчета процессов в единую компьютерную систему на общей информационной и методологической основе. Разработанная в ФГБНУ «ВНИИМП им. В.М. Горбатова» система SSS Bio [8] предназначена для обработки данных, полученных в ходе выполнения НИР, и оптимизации экспериментальных исследований процессов на стадии их изучения в лабораторных условиях. Путем формализации ряда этапов компьютерная система SSS Bio позволяет решить задачи оптимального планирования эксперимента, проведения статистического анализа результатов, исследования кинетики и проведения технологического расчета, определенного множества вариантов организации исследуемого процесса.

Однако, по мнению специалиста, имеющего 20-летний опыт работы со статистическими пакетами, University of California, Los Angeles (www.ucla.edu) M. Митчела [9], если специалист не обладает достаточными знаниями и компетенциями, то даже самый совершенный программный продукт не позволит провести качественный анализ данных. (apparatus of fuzzy logic, swarm and genetic algorithms); a role of a construction tool for computer training -modeling media (multiagent modeling).

Prospects for development of the meat processing industry to a large extent depend on effectiveness of scientific investigations in the field of applied biotechnology and introduction of their results into production. When solving the tasks of managing scientific investigations, it is necessary to evaluate their prospectivity, determine a contribution of certain developments in solutions to set tasks, create a strategy of incorporation of the obtained results. Due to the complexity and depth of the listed problems, there is a need for specialists with knowledge of specific technologies of meat raw material processing and experience in using the means of computer technologies.

The majority of the developed automated and computer packages of applied software programs for processing of experimental data with the use of the statistical methods (Statistica, SPSS - Statistical Package for Social Science, MatLab, MathCad, MuMath, Statgraf, analysis package in MS Excel and others) are informatively and methodologically independent of the following technological calculations and project designs. A review of the universal statistical packages on one of the most important indicator, functionality, is presented in [7].

To commercialize and accelerate introduction of research developments into production, consolidation of knowledge in the field of mathematical modeling, information technologies and the technology in the computer system of experiment planning with the sub-system of process technological calculation into a united computer system on the common information and methodological basis is promising. The SSS Bio developed in FGBNU «The V.M. Gorbatov VNIIMP» [8] is intended to process data obtained during experimental research and to optimize experimental research processes at the stage of their analysis in the laboratory conditions. By formalization of the several stages, the SSS Bio computer system allows solving problems of optimal experimental planning, carrying out statistical analysis of the results, studying kinetics and performing technological calculations for multiple organization options for a process under investigation.

However, according to M. Mitchell, a specialist with 20-year experience in working with statistical packages from the University of California, Los Angeles (www.ucla.edu) [9], if a specialist does not have enough knowledge and competence than even a perfect program product will not be useful for high quality data analysis. 
Целью данной работы - показать возможности работы в компьютерной системе SSS Bio, осуществляющей обработку статистических данных (получение стохастической зависимости (математическая модель) методами активного и пассивного эксперимента).

\section{Материалы и методы}

SSS Bio разработана в среде программирования Embarcadero Delphi 2010. Программа прошла тестирование и апробацию на персональном компьютере с 64-х разрядной операционной системой Microsoft Windows 7. При создании SSS Віо использовался сторонний модуль Matrixes.pas. Данный модуль реализован «JKCoders Team», имеет актуальную версию 1.0 и используется для реализации класса TMatrix, который позволяет совершать основные действия над матрицами. Структурная схема системы представлена на Рис. 2.

Обработка экспериментальных данных дает возможность подтвердить реально существующие закономерности между исследуемыми параметрами, зафиксированными в ходе проведения эксперимента.

Обработка экспериментальных данных необходима: для оценки истинного значения измеряемой вели-
The aim of this work is to show the possibilities of the work in the computer system SSS Bio that processes statistical data (obtaining the stochastic dependence (the mathematical model) by the methods of the active and passive experiment).

\section{Materials and methods}

SSS Bio was developed in the programming environment Embarcadero Delphi 2010. The program was tested on a personal computer with 64-bit operating system Microsoft Windows 7. When designing SSS Bio, the external module Matrices.pas was used. This module was realized by JKCoders Team, has the actual version 1.0 and is used for realization of TMatrix class, which allows performing the main actions on matrices. The structure diagram of the system is presented in Fig. 2.

Processing of the experimental data allows confirming the real regularities between studied parameters that were recorded during an experiment.

Processing of experimental data is necessary to assess the real value of a measured parameter and accuracy of pa-

Система SSS Bio | SSS Bio System

\begin{tabular}{|c|c|}
\hline \multicolumn{2}{|r|}{$\begin{array}{c}\text { Пассивный эксперимент | } \\
\text { passive experiment }\end{array}$} \\
\hline & $\begin{array}{c}\text { Однофакторный дисперсион- } \\
\text { ный анализ | one-way analysis of } \\
\text { variance }\end{array}$ \\
\hline & $\begin{array}{c}\text { Корреляционный анализ } \\
\text { correlation analysis }\end{array}$ \\
\hline & $\begin{array}{c}\text { Ранговая корреляция | } \\
\text { rank correlation with } \\
\text { - Статистика Спирмена | } \\
\text { Ореarman's statistics } \\
\text { - Статистика Кендалла | } \\
\text { Кendall's statistics }\end{array}$ \\
\hline & 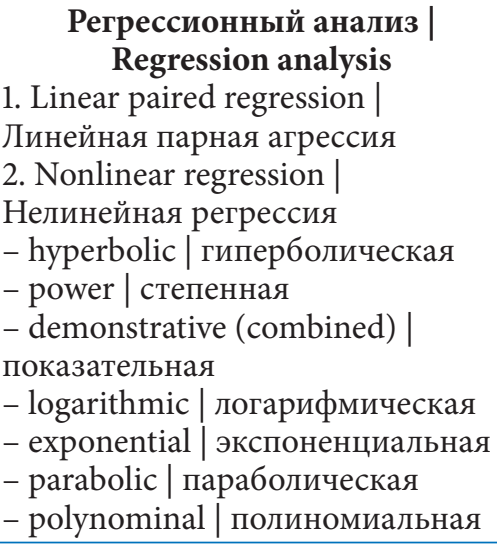 \\
\hline & $\begin{array}{c}\text { Множественная регрессия } \\
\text { Multiple regression }\end{array}$ \\
\hline
\end{tabular}

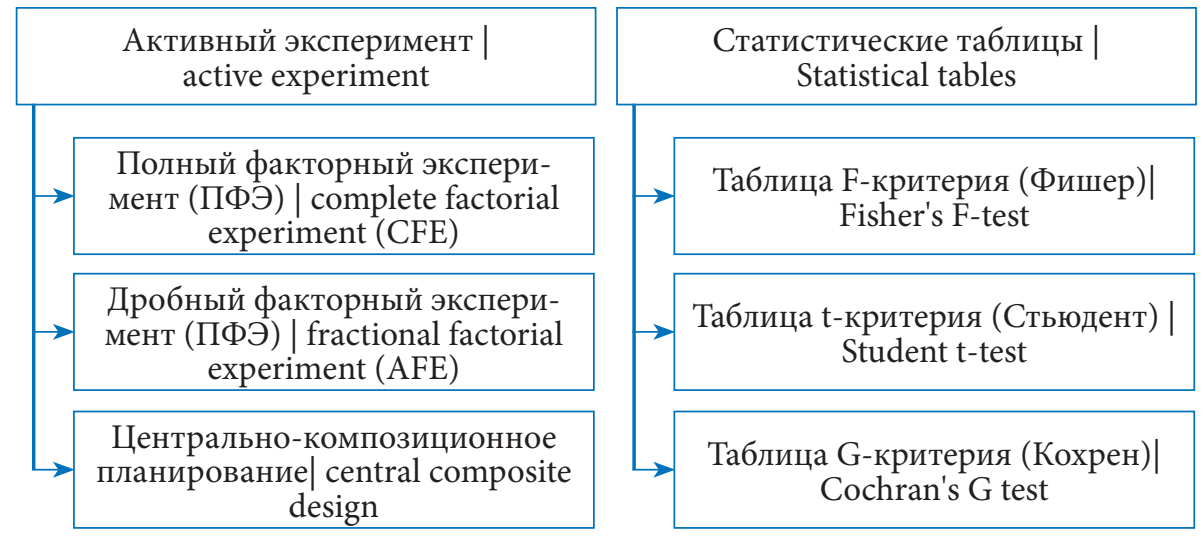

Fig. 2. The structure diagram of the SSS Bio system

Рис. 2. Структурная схема системы SSS Bio 
чины; для оценки точности измерения величины; для сопоставления двух методов анализа или способа производства; для установления корреляционной и функциональной зависимостей.

Все экспериментальные исследования объединяет общность логической схемы [10], по которой они строятся и которую можно представить в виде следующего алгоритма (Рис. 3).

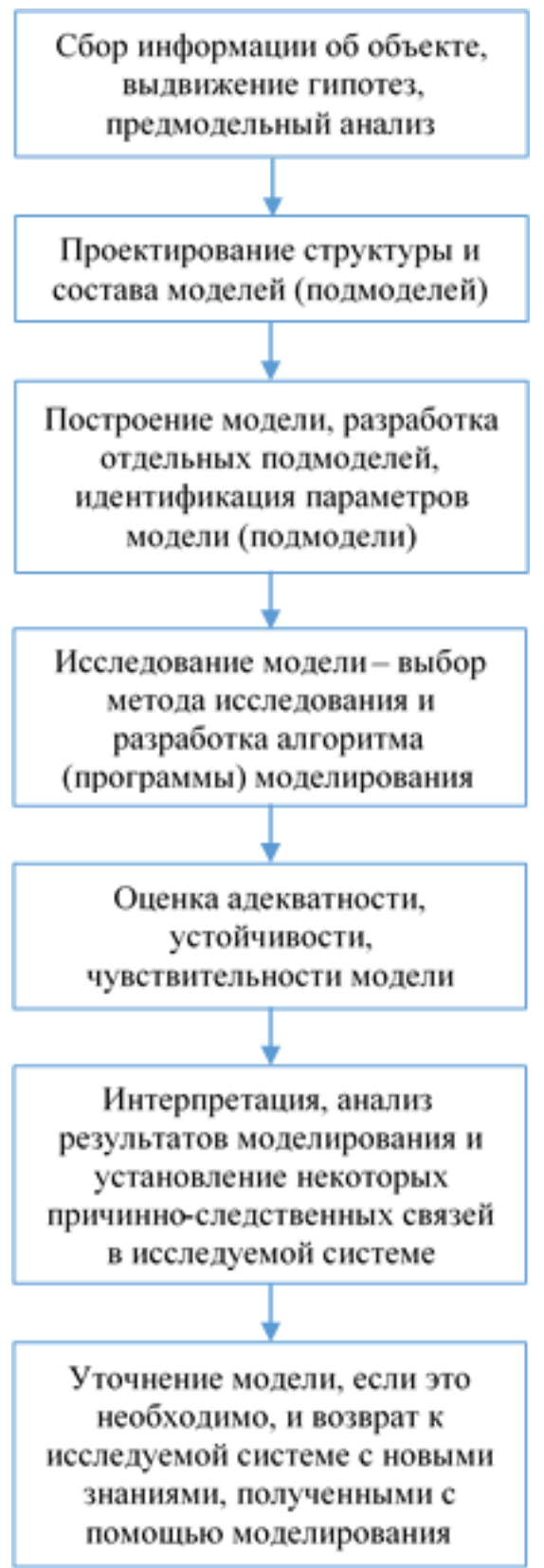

Рис. 3. Цикл моделируемой системы

\section{Результаты и обсуждение}

В качестве примера работы системы рассмотрим несколько модулей.

Первый из них - Однофакторныци дисперсионный анализ. При проведении экспериментальных исследований на выходную величину (отклик Y) оказывают влияние входные переменные (параметры), не поддающиеся количественному описанию. Такими факто- rameter measurement, to compare two methods of analysis or methods of production, to establish correlation and functional dependency.

All experimental investigations are united by generality of a logical design [10], according to which they are build and which can be presented in the form of the following algorithm (Fig. 3).

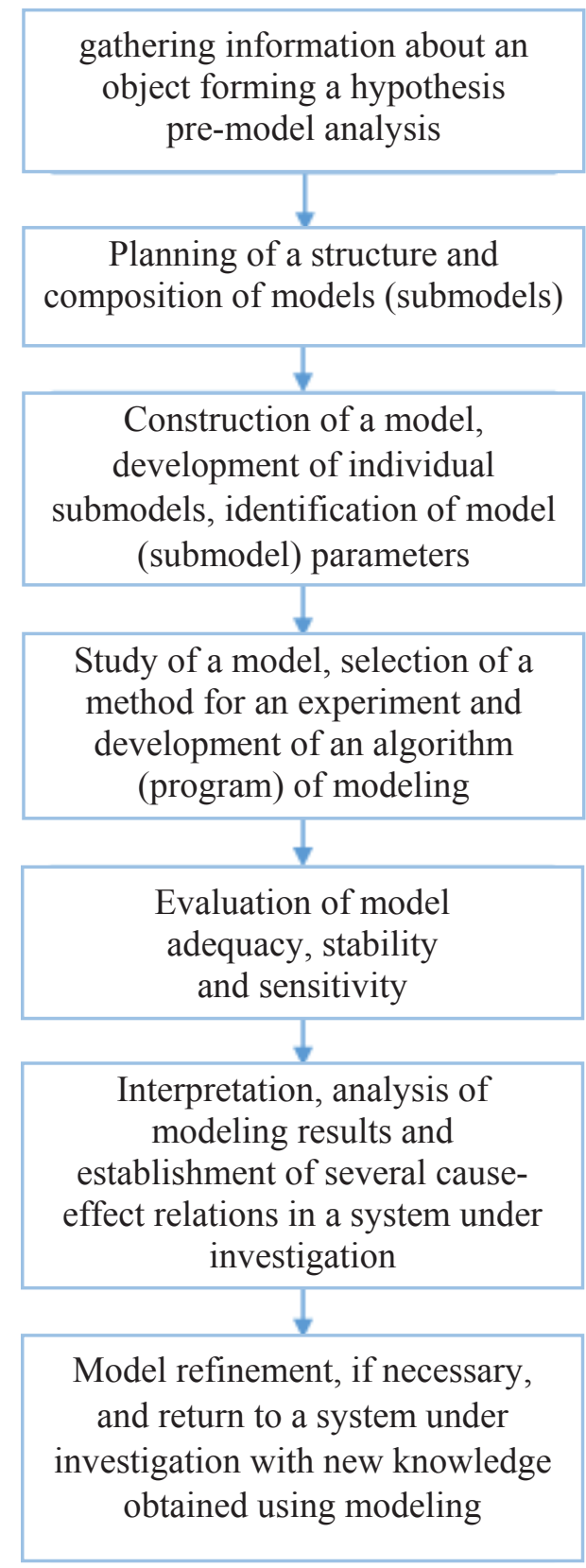

Fig. 3. Modeling system cycle

\section{Results and discussions}

Let's consider several modules as an example of system operation.

The first of them is the one-way analysis of variance. In an experiment, the output value (the response $y$ ) is influenced by the input variables (parameters) that defy quantitative description. These factors can be controllable and 
рами могут быть управляемые и неуправляемые переменные. Для изучения влияния факторов такого рода на отклик, их общего оценивания, ранжирования и выделения среди них существенных применяется дисперсионный анализ.

При отработке модуля однофакторного дисперсионного анализа использовали данные [11] для установления влияния (значимости) питательных сред на накопление пастерелл. Данные представлены на Рис. 4. В случае выявления данного фактора, необходимо установить питательную среду, обеспечивающую наибольшее накопление пастерелл. Откликом Y является величина оптической плотности (экстинкция), характеризующая накопление микроорганизмов (пастерелл). Чем больше величина оптической плотности, тем больше накопление пастерелл и, следовательно, лучшая питательная среда. Исследуется влияние одного качественного раствора, который варьируется на четырех уровнях: $\mathrm{A}(1), \mathrm{B}(2)$, $\mathrm{C}(3), \mathrm{D}(4)-\mathrm{i}=1,2,3,4$. Эксперимент проводится с четырьмя повторными опытами $(\mathrm{m}=4)$. Общее количество опытов равно 16.



\begin{tabular}{|c|c|c|c|c|}
\hline & $A(1)$ & $B(2)$ & $C(3)$ & $D(4)$ \\
\hline Опыт 1 & 1,30 & 2,70 & 2,20 & 2,10 \\
\hline Опыт 2 & 1,50 & 2,00 & 2,00 & 1,70 \\
\hline Oпыт 3 & 1,70 & 2,20 & 2,00 & 1,40 \\
\hline Oпыт 4 & 1,90 & 2,40 & 2,10 & 1,80 \\
\hline \multicolumn{5}{|l|}{ Среднее } \\
\hline Дисп-я & & & & \\
\hline
\end{tabular}

uncontrollable variables. The analysis of variance is used to study an influence of such factors on a response, their total evaluation, ranking and selection of significant factors among them.

To refine the module of the one-way analysis of variance, we used the data [11] for establishing an effect (significance) of culture media on accumulation of Pasteurella. The data are presented in Fig. 4. In case of determining this factor, it is necessary to find a culture medium that ensures the highest accumulation of Pasteurella. The response $y$ is a value of optical density (extinction) that characterizes an accumulation of microorganisms (Pasteurella). The higher an optical density value, the higher an accumulation of Pasteurella and, consequently, the better a culture medium. An effect of a qualitative solution, which is varied on four levels ( $\mathrm{A}(1), \mathrm{B}(2), \mathrm{C}(3), \mathrm{D}(4)-\mathrm{i}=1,2,3,4)$ is studied. The experiment is carried out in four replicates $(\mathrm{m}=4)$. The total number of experiments is 16 .

Fig. 4. Single factor experimental design | Рис. 4. Однофакторный план эксперимента

План эксперимента представляет собой однофакторную классификацию дисперсионного анализа: экспериментальные данные сгруппированы по четырем уровням одного фактора. План сбалансирован, поскольку число повторных опытов для всех уровней фактора одно и то же.

В результате проведения дисперсионного анализа, программа SSS Bio предоставляет исчерпывающее количество статистических данных (Табл. 1).

Модель дисперсионного анализа для однофакторного эксперимента представляется следующей формулой

$$
y_{i m}=\mu+a_{i}+\varepsilon_{i m}
$$

где $y_{\text {im }}$ - отклик, полученный на $i$-ом уровне фактора А в $m$-ой повторности; $\mu$ - общее среднее, отражающее общий уровень всех результатов (т.е. среднее из $i$ средних значений по столбцам, постоянное для всех данных); $a_{i}$ - эффект $i$-го уровня фактора; $\varepsilon_{i m}-$ случайная ошибка в $m$-ом наблюдении на $i$-ом уровне.

Важной особенностью всех статистических обработок является интерпретация полученных результатов. Существует довольно распространенное мнение, что 
Table 1. The results of the analysis of variance | Табл. 1. Результаты дисперсионного анализа

\begin{tabular}{|l|l|l|l|l|}
\hline & $\mathrm{A}(1)$ & $\mathrm{B}(2)$ & $\mathrm{C}(3)$ & $\mathrm{D}(4)$ \\
\hline Опыт 1 & 1,30 & 2,70 & 2,20 & 2,10 \\
\hline Опыт 2 & 1,50 & 2,00 & 2,00 & 1,70 \\
\hline Опыт 3 & 1,70 & 2,20 & 2,00 & 1,40 \\
\hline Опыт 4 & 1,90 & 2,40 & 2,10 & 1,80 \\
\hline Среднее & 1,6 & 2,325 & 2,075 & 1,75 \\
\hline Дисп-я & 0,067 & 0,089 & 0,009 & 0,083 \\
\hline
\end{tabular}

Mean squared deviations (MSD) associated with dispersion by parallel experiments on each level:

S[1]: 0.20 S[2]: 0.27 S[3]: 0.03 S[4]: 0.25|Среднеквадратичные отклонения связанные с рассеиванием по параллельным опытам на каждом уровне:

$S[1]: 0,20 S[2]: 0,27 S[3]: 0,03 S[4]: 0,25$

Mean squared deviations (MSD): | Среднеквадратичные отклонения:

Deviations associated with dispersion

relative to overall mean $\left(\mathrm{S}_{\text {res }}\right): 2.02 \mid$ Отклонения, связанные

с рассеиванием относительно общего среднего (Sост): 2,02

Deviations associated with dispersion between levels

of a factor - interlevel (Sfact): 1.27| Отклонения,

связанные с рассеиванием между уровнями фактора -

междууровневые (Sфакт): 1,27

Deviations associated with dispersion inside sampling -

intralevel (Sr): 0.74 | Отклонения, связанные с рассеиванием

внутри выборки по уровням - внутриуровневые (Sr): 0,74

$\mathrm{G}=0.3591$ - dispersions are uniform $\mid \mathrm{G}=0,3591$ - дисперсии однородны.

Factor dispersion $=0.4242 \mid$ Факторная дисперсия $=0,4242$

Residual dispersion $=\mathbf{0 . 1 8 3 4} \mid$ Остаточная дисперсия $=0,1834$

Repeatability dispersion $=0.093 \mid$ Дисперсия

воспроизводимости $=0,0931$

$\mathrm{F}=\mathbf{6 . 8 3 2} \mid \mathrm{F}=\mathbf{6 , 8 3 2}$

An effect of a factor is established. | Влияние фактора установлено.

результаты дисперсионного анализа в виде значимости или незначимости по критерию Фишера и процедуры множественного сравнения являются окончательными. Но это явно ошибочное мнение. Конечным этапом должен быть перевод полученных результатов со статистического языка с его уровнями значимости, ошибками первого и второго рода, ложностью нулевой гипотезы $\left(\mathrm{H}_{0}\right)$ и т.д. на содержательный язык. Окончательные выводы должны быть сделаны в терминах той области исследования, в которой был проведен эксперимент [11].

Из таблицы 1 следует, что фактор значим $\left(\mathrm{F}=6,832>\mathrm{F}_{\text {крит }}=3,48\right)$. Это означает, что среди уровней фактора есть такие, которые отличаются друг от друга. Для определения различий между уровнями факторов использован метод множественных сравнений Шеффе (Табл. 2). form of significance or insignificance by Fisher's F-test and procedures of multiple comparisons are conclusive. However, it is an unsound opinion. The final stage should be translation of the obtained results from the statistical language with its levels of significance, errors of the first and second kind, falseness of the null hypothesis ( $\mathrm{H} 0)$ etc. into the comprehensive language. The definitive conclusions are to be made in the terms of the field of investigations, in which an experiment was carried out [11].

It follows from Table 1 that the factor is significant $\left(\mathrm{F}=6.832>\mathrm{F}_{\text {crit }}=3.48\right)$. This means that among the levels of the factor are those that are different from each other. To determine the differences between the levels of the factors, the Sheffe's multiple-comparisons method was used (Table 2).

Table 2. Sheffe's multiple-comparisons method | Табл. 2 Множественные сравнения по методу Шеффе

\begin{tabular}{|c|c|c|c|c|c|c|c|}
\hline Factor level | Уровень фактора & Mean value | Среднее значение & \multicolumn{3}{|c|}{ Paired comparisons } & \multicolumn{3}{|c|}{ Парные сравнения } \\
\hline $\mathrm{A}(1)$ & $1.60 \pm$ & 1 & $2^{*}$ & 1 & 3 & 1 & 4 \\
\hline $\mathrm{B}(2)$ & $2.33 \pm$ & 2 & 3 & 2 & $4^{\star}$ & & \\
\hline $\mathrm{C}(3)$ & $2.08 \pm$ & 3 & 4 & & & & \\
\hline $\mathrm{D}(4)$ & $1.75 \pm$ & & & & & & \\
\hline
\end{tabular}

Звездочкой отмечены те пары, внутри которых уровни значимо отличаются друг от друга. Из результатов парных сравнений строится следующий ряд предпочтительности $\mathrm{A}(1)=\mathrm{D}(4)<\mathrm{B}(2)=\mathrm{C}(3)$. Ширина $95 \%$ доверительного интервала для уровней фактора равна $0,27$.

Полученные данные говорят о том, что питательные среды, соответствующие уровням $\mathrm{B}(2)$ и $\mathrm{C}(3)$ обеспечивают большее накопление пастарелл, чем среды $\mathrm{A}(1)$ и $\mathrm{D}(4)$.

В технологических исследованиях часто решают задачу выявления факторов, определяющих уровень и динамику (кинетику) протекания технологического процесса. Такая задача чаще всего решается методами регрессионного анализа. Для достоверного отображе-
The asterisk marks the pairs, within which the levels are significantly different from each other. From the results of the paired comparisons, the following row of preference $\mathrm{A}(1)=\mathrm{D}(4)<\mathrm{B}(2)=\mathrm{C}(3)$ is built. The width of the $95 \%$ confidence interval for the factor levels is 0.27 .

The obtained data suggest that the culture media that correspond to the levels $\mathrm{B}(2)$ and $\mathrm{C}(3)$ ensure higher accumulation of Pasteurella compared to the media A(1) and $\mathrm{D}(4)$.

In technological investigations, a task of revealing factors that determine a level and dynamics (kinetics) of the technological process is often solved. This task is more frequently solved by the methods of the regression analysis. For the reliable reflection of the processes that objectively exist in technology, it is necessary to find significant rela- 
ния объективно существующих в технологии процессов необходимо выявить существенные взаимосвязи и не только выявить, но и дать им количественную оценку. Этот подход требует вскрытия причинных зависимостей. Под причинной зависимостью понимается такая связь между процессами, когда изменение одного из них является следствием изменения другого (например, влияние массовой доли хлорида натрия на активность воды в мясных изделиях).С этой целью используются два модуля компьютерной системы SSS Bio - корреляционный анализ; регрессионный анализ.

Модуль 2 - Регрессионный анализ. Произведем расчет и выявим зависимость между процентом замены мясного сырья белком плазмы крови и содержанием влаги в мясном фарше. Исходные данные представлены на Рис. 5.



\begin{tabular}{|l|l|l|l|l|}
\hline & $X$ & $Y$ & $X * X$ & $X Y$ \\
\hline 1 & 10 & 67,9 & & \\
\hline 2 & 15 & 69,6 & \\
\hline 3 & 20 & 71,3 & \\
\hline 4 & 25 & 72,4 & \\
\hline 5 & 30 & 73,1 & & \\
\cline { 1 - 1 } Сумма & & & & \\
\hline
\end{tabular}

Fig. 5. Regression analysis | Рис. 5. Регрессионный анализ

В результате проведения регрессионного анализа получены следующие статистические данные (Табл. 3) на основании которых технолог может спрогнозировать поведение мясной системы и принять обоснованное решение в каком диапазоне рациональнее (лучше) осуществить замену мясного сырья белковыми добавками. tionships, and not only find but also give them quantitative assessment. This approach requires detection of causal dependencies.

A causal dependency is a relation between processes, when a change in one of them is a consequence of changes in another (for example, an effect of mass fraction of sodium chloride on water activity in meat products). To this end, two modules of the computer system SSS Bio are used: correlation analysis and regression analysis.

Module 2 - Regression analysis. Let's carry out calculations and determine a dependency between a percent of meat raw material replacement with blood plasma protein and the water content in sausage meat. The initial data are presented in Fig. 5.

Table 3. The results of the regression analysis | Табл. 3 Результаты регрессионного анализа

\begin{tabular}{|l|l|l|l|l|}
\hline \multicolumn{5}{|c|}{ Text Field «Information» } \\
\hline & X & Tекстовое поле «Информац & X $^{*}$ X & XV \\
\hline 1 & 10 & 67,9 & 100,00 & 679,00 \\
\hline 2 & 15 & 69,6 & 225,00 & 1044,00 \\
\hline 3 & 20 & 71,3 & 400,00 & 1426,00 \\
\hline 4 & 25 & 72,4 & 625,00 & 1810,00 \\
\hline 5 & 30 & 73,1 & 900,00 & 2193,00 \\
\hline Сумма & 100,00 & 354,30 & 2250,00 & 7152,00 \\
\hline
\end{tabular}

Coefficient $\mathrm{a}=\mathbf{6 5 . 5 8} \mid$ Коэффициент $\mathrm{a}=\mathbf{6 5 , 5 8}$

Coefficient $b=0.26 \mid$ Коэффициент $b=0,26$

Correlation coefficient: $r=0.9857$ | Коэффициент корреляции: $r=0,9857$

Determination coefficient: $\mathbf{R}^{2}=0.972 \mid$ Коэффициент детерминации:

$\mathbf{R}^{2}=\mathbf{0 , 9 7 2}$

Regression equation: $\mathrm{Y}=65.5800+0.2640 * \mathrm{X} \mid$ Уравнение регрессии:

$\mathrm{Y}=65,5800+0,2640$ * $\mathrm{X}$

Student test $\mathrm{t}_{\mathrm{b}}=10.1438 \mid$ Критерий Стьюдента $\mathrm{t}_{\mathrm{b}}=10,1438$

Student test $\mathrm{t}_{\mathrm{b}}=118.7856 \mid$ Критерий Стьюдента $\mathrm{t}_{\mathrm{a}}=118,7856$

Confidential interval for $\alpha$ and $\beta$ : | Доверительные интервалы для $\alpha$ и $\beta$ :

$0.197<\beta<0.331$

$64.159<\alpha<67.001$

The analyzed dependence is statistically significant! | Исследуемая

зависимость статистически значима

$\mathrm{F}=\mathbf{1 0 2 . 8 9 7 6}$

The model is adequate! | Модель адекватна
As a result of the regression analysis, the following statistical data were obtained (Table 3), on which basis a technologist can predict a behavior of a meat system and make a grounded decision regarding a range of the most rational (the best) replacement of meat raw material with protein additives. 
Для оценки точности проведенных исследований большое значение имеет доверительный интервал. Исследования считаются достоверными, если результаты эксперимента не выходят за пределы доверительного интервала. Этот интервал показывает, в каких пределах колеблется точная величина исследуемого показателя в сравнении с генеральным средним.

Важной особенностью SSS Вiо является возможность построения графиков стохастических зависимостей (математической модели), а также наглядное представление расположения выборки (Рис. 6). Данная функция позволяет визуально оценить корреляционно-регрессионную зависимость.
To assess the accuracy of performed investigations, a confidence interval is of high importance. Investigations are considered reliable if the experimental results do not exceed the limits of a confidence interval. The confidence interval shows limits, within which a precise value of the studied indicator varies compared to the universe mean.

An important peculiarity of the SSS Bio is a possibility to construct stochastic dependency graphs (a mathematical model) as well as a demonstrative presentation of sampling distribution (Fig. 6). This function allows a visual assessment of the correlation-regression dependency.
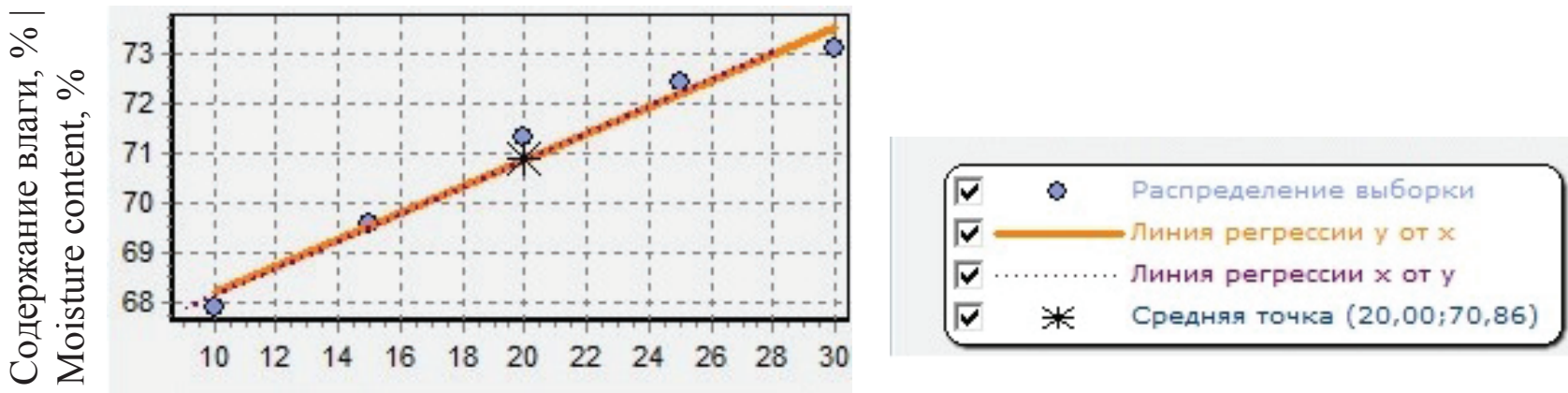

Уровень замены мясного сырья, \% | The level of meat raw material replacement, \%

Fig. 6. Graphs of regression lines and sampling | Рис. 6 Графики линий регрессии и распределение выборки

Анализ полученных результатов показывает, что с увеличением процента замены мясного сырья белковыми добавками увеличивается содержание влаги и уменьшается содержание жира и белка в мясном фарше.

Однако, согласно соотношению белок: вода в готовой продукции $B=(5 \times 4)+10,(B-$ максимально допустимое содержание влаги в продукте, $\% ; ~ Б-$ массовая доля белка в продукте,\%), действующему в ряде стран Евросоюза и США применительно к группе мясопродуктов высших и первых сортов, чем больше массовая доля белка в колбасных и мясных продуктах, тем больше воды в них может содержаться [1].

Для большинства мясопродуктов традиционных рецептур и технологий значения соотношения вода: белок находятся в интервале от 4,1 до 5,0.

Изменения функциональных свойств фарша находятся в зависимости от содержания в нем влаги, белка, жира и их соотношений. Компьютерная система SSS Bio позволяет по экспериментальным данным получить математические модели ВСС, ВУС и ЖСС в колбасном фарше с использованием соевого изолированного белка в зависимости от содержания жира и белка (Модуль - Множественная регрессия).

На примере содержания общего белка (X1) и жира (X2) в колбасном фарше покажем изменение ВСС (Y). Исходные данные представлены на Рис. 7.

В Табл. 4 представлены результаты обработки исходных данных.
Analysis of the obtained results shows that with an increase in a percentage of meat raw material replacement with protein additives, the moisture content increases, while the fat and protein content decreases in sausage meat.

However, according to the protein: water ratio in the finished products $B=(5 \times 4)+10,(B-$ maximum allowable water content in a product, $\% ; 5$ - protein mass fraction in a product, \%) that exists in several EC states and the USA for the group of meat products of higher and first grades, the higher protein mass fraction in sausages and meat products, the higher water they can contain [1].

For most meat products of the traditional recipes and technologies, the value of the water: protein ratio is in a range from 4.1 to 5.0 .

Changes in the functional properties of sausage meat depend on the content of moisture, protein and fat, as well as their ratio. On the basis of experimental data, the computer system SSS Bio allows obtaining mathematical models of MBC, BHC and FBC in sausage meat with isolated soya protein depending on the fat and protein content (The module - multiple regression).

We will show the changes in $\mathrm{MBC}(\mathrm{Y})$ by the example of the total protein (X1) and fat (X2) content in sausage meat. The initial data are presented in Fig.7.

Table 4 presents the results of the initial data processing. 


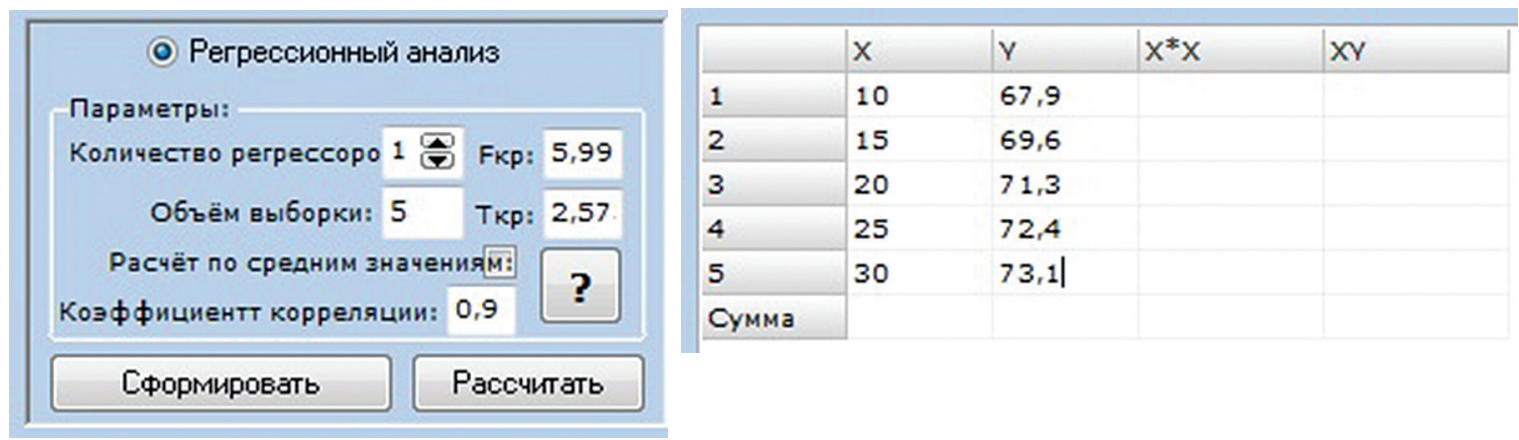

Fig. 7. Multiple regression | Рис. 7. Множественная регрессия

Table 4. Results of the multiple regression | Табл. 4 Результаты множественной регрессии

Text Field «Information» | Текстовое поле «Информация»

Coefficient $b_{0}=-8.94 \mid$ Коэффициент $b_{0}=-8,94$

Coefficient $b_{1}=-39.69 \mid$ Коэффициент $b_{1}=-39,69$

Coefficient $b_{2}=37.72 \mid$ Коэффициент $b_{2}=37,72$

Regression equation: | Уравнение регрессии:

$\mathrm{Y}=-8.94-39.69 * \mathrm{X} 1+37.72^{\star} \mathrm{X} 2$

Adequacy dispersion, $\mathrm{S}^{2}=0.98 \mid$ Дисперсия адекватности, $\mathrm{S}^{2}=0,98$

Factorial dispersion, $S_{\text {fact }}^{2}=0.44 \mid$ Факторная дисперсия, $S_{\text {факт }}^{2}=0,44$

$\mathrm{F}=\mathbf{2 2 . 0 4}$

The model is adequate! | Модель адекватна

Значение коэффициента множественной корреляции $(\mathrm{R}=0,98)$ указывает на высокую степень линейной зависимости Y от двух объясняющих переменных X1 и Х2.

Из таблицы 4 следует, что модель адекватна $\left(\mathrm{F}=22,04>\mathrm{F}_{\text {крит }}=6,94\right)$. Это означает, что полученное уравнение регрессии хорошо согласуется с экспериментальными данными и может быть использовано в дальнейших исследованиях. Графическое отображение полученного уравнения представлено на Рис. 8.

$$
\mathrm{Y}=-8,94-39,69 \mathrm{X}_{1}+37,72^{\star} \mathrm{X}_{2}
$$

Additional Text Field | Дополнительное текстовое поле Paired correlation coefficient between $\mathrm{x} 1$ and $\mathrm{Y}, \mathrm{Ry} 1=-0.41$ Коэффициент парной корреляции между х1 и Y, Ryl=-0,41 Paired correlation coefficient between $\mathrm{x} 2$ and $\mathrm{Y}, \mathrm{Ry} 2=0.14$ Коэффициент парной корреляции между х2 и Y, Ry2=0,14 Paired correlation coefficient between $\mathrm{x} 1$ and $\mathrm{x} 2, \mathrm{R} 12=0.84$ Коэффициент парной корреляции между х1 и х2, R12=0,84 Multiple regression coefficient, $R=0.98$

Коэффициент множественной регрессии, $\mathrm{R}=0,98$

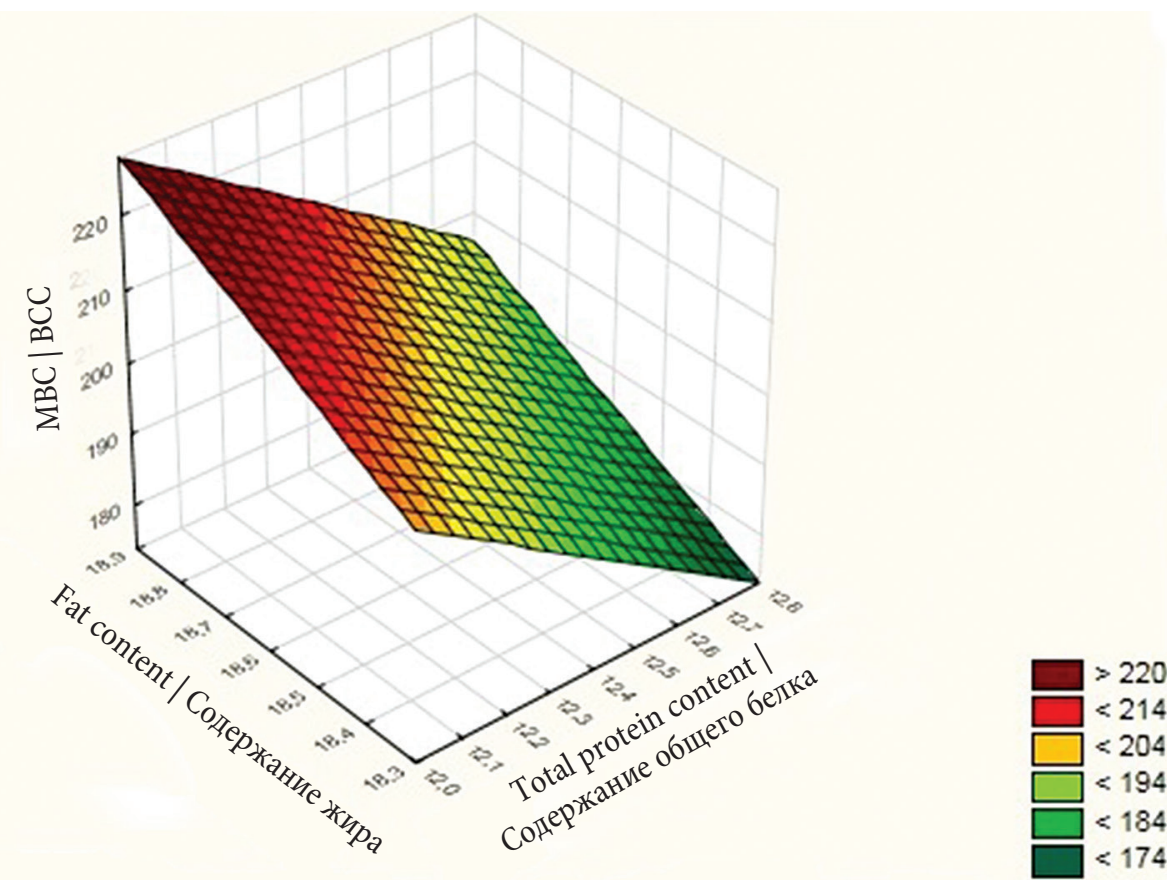

Fig. 8. A response surface of an effect of the total protein and fat content on sausage meat MBC

Рис. 8. Поверхность отклика влияния содержания общего белка и жира на ВСС колбасного фарша 
Анализ полученного уравнения показывает, что изменение ВСС зависит от содержания общего белка и жира в колбасном фарше. При постоянном уровне жира увеличение общего содержания белка способствует росту ВСС фарша. Однако рост ВСС на единицу белка уменьшается с увеличением количества жира, что согласуется с данными Салаватулиной Р.М., Любченко В.И. [12, 13].

\section{Выводы}

Информационные технологии, реалируемые с помощью программного обеспечения компьютера, могут многое. Они неизмеримо увеличивают наши вычислительные возможности. Они могут хранить и оперативно обрабатывать большие объемы информации.

Методы математической статистики, реализуемые в компьютерной программе SSS Bio, расширяют возможности научного прогнозирования и целесообразного принятия решений в условиях неопределенности, когда исследователю принципиально не может быть известен весь комплекс условий проведения эксперимента. На примерах пассивного эксперимента (однофакторного дисперсионного анализа, множественной линейной регрессии) показана работа в SSS Bio.

\section{БИБЛИОГРАФИЧЕСКИИ СПИСОК}

1. Жаринов А.И. Основы современных технологий переработки мяса. Ч. 1. Эмульгированные и грубоизмельченные мясопродукты / под редакцией Воякина М.П. - М.: ИТАР-ТАСС.1994. - 154 с. (C. 71-73)

2. Глинский Б.А., Грязнов Б.С., Аынин Б.С., Никитин Е.П. Моделирование как метод научного познания: гносеологический анализ. - М.: Издательство МГУ. - 1965. - С. 248.

3. Аристотель. Метафизика / пер. А.В. Кубицкого. - М.: Эксмо. $-2006 .-608$ c.

4. Dodig-Crnkovic G. Scientific Methods in Computer Science [Электронный pecypc: http://www.mrtc.mdh.se/ publications/0446.pdf. Аата обращения 10.07.2017].

5. Хрущев С.С., Абатурова А.М., Аьяконова А.Н., Устинин А.М., Зленко А.В., Федоров В.А., Коваленко И.Б., Ризниченко Г.Ю., Рубин А.Б. Моделирование белок-белковыхвзаимодействий с применением комплекса многочастичной броуновской динамики PropKSim. // Компьютерные исследования и моделирование. - 2013. - Т. 5. - № 1. C. 47-64.

6. Matuszek J., Jasik L. Modelling and Simulation food products production. [Электронный pecypc: https://www.researchgate. net/institution/University_of_Bielsko-Biala. Аата обращения 12.08.2017]

7. Самуйленко А.Я., Еремец В.И., Скотникова Т.А., Неминущая А.А., Провоторова О.В., Фролов Ю.А., Ковальский И.В. Чубаров М.В. Перспективы использования программных средств статистической обработки данных в биотехнологических исследованиях. // Вестник Российской сельскохозяйственной науки. -2016 . - № 6. - С. 8-11.

8. Подсистема статистического обеспечения биологических исследований / А.Б. Аисицын, М.А. Никитина, А.Н. Захаров, Е.Б. Сусь // Свидетельство о регистрации программ Аля ЭВМ № 2016613478 от 28.03.2016. - М.: Роспатент, 2016.

9. Mitchell M.M. Strategically using General Purpose Statistics Packages: A Look at Stata, SAS and SPS. USLA ATS Statistical Consulting Group, Technical Report Series, Report \#1. [Электроныйресурс: http://www.ats.ucla.edu/stat/technical-reports/ number1_editedFeb_2_2007/ucla_ATSstat_trl_1.1_0207.pdf. Аата обращения 08.06.2017].
Analysis of the obtained equation demonstrates that changes in MBC depend on the content of total protein and fat in sausage meat. At the constant fat level, an increase in the total protein content contributes to an increase in sausage meat MBC. However, an increase in MBC per protein unit is decreased with an increase in the fat amount, which corresponds to the data of Salavatulina R.M. and Lubchenko V.I. $[12,13]$

\section{Conclusions}

The information technologies realized with program software can do many things. They immeasurably increase our computational capabilities. They can store and operatively process high volumes of information.

The methods of the mathematical statistics realized in the computer program SSS Bio extend our possibilities of scientific prediction and expedient decision making in the uncertain conditions, when a researcher, in principle, cannot know the whole complex of experimental conditions. The work in SSS Bio has been shown by the example of the passive experiment (one-way analysis of variance and multiple linear regression)

\section{REFERENCES}

1. Zharinov A.I. The principles of modern meat processing technologies. Part 1. Emulsified and coarsely minced meat products/ under the editorship of Voyakin M.P. - M. ITAR-TASS.- 1994.154 pages (PP. 71-73)

2. Glinsky B.A., Gryaznov B.S., Dynin B.S., Nikitin E.P. Modeling as a method of scientific knowledge; gnoseological analysis. M.: MGU Publishing House.- 1965. - P. 248.

3. Aristotle. Metaphysics / translation by A.V. Kubitsky. - M. EKSMO. - 2006. -608 pages.

4. Dodig-Crnkovic G. Scientific Methods in Computer Science [Эмектронный ресурс: http://www.mrtc.mdh.se/publications/0446.pdf. Аата обращения 10.07.2017].

5. Khrushchev S.S., Abaturova A.M., Diakonova A.N., Ustinin D.M., Zlenko D.V., Fedorov V.A., Kovalenko I.B., Riznichenko G.Yu., Rubin A.B. (2013). Multi-particle Brownian Dynamics software ProKSimfor protein-protein interactions modeling. Computer Research and Modeling, 5, 47-64.

6. Matuszek J., Jasik L. Modelling and Simulation food products production. [Электронный pecypc: https://www.researchgate. net/institution/University_of_Bielsko-Biala. Аата обращения 12.08.2017]

7. Samuylenko A.Ya., Eremets V.I., Skotnikova T.A., Neminushchaya L.A., Provotorova O.V., Frolov Yu.D., Kovalski I.V., Chubarov M.V. (2016).The Perspectives of the software tools used for the statistical data processing in biotechnological researches. Herald of the Russian Agricultural science, 6, 8-11.

8. Statistical support subsystem for biological research A.B. Lisitsyn, M.A. Nikitina, A.N. Zakharov, E.B. Sus' // Certificate of Registration of the Computer Program No. 2016613478 of 28.03.2016. - M.: RosPatent, 2016.

9. Mitchell M.M. Strategically using General Purpose Statistics Packages: A Look at Stata, SAS and SPS. USLA ATS Statistical Consulting Group, Technical Report Series, Report \#1. ГЭлектронный pecypc: http://www.ats.ucla.edu/stat/technical-reports/num ber1_editedFeb_2_2007/ucla_ATSstat_trl_1.1_0207.pdf. Аата обращения 08.06.2017].

10. Sovetov B.Ya, Yakovlev S.A. Modeling of systems. - M.: Yurayt.- 2017.- 343 pages. (PP. 188-195). - ISBN: 978-59916-3916-3. 
10. Советов Б.Я., Яковлев С.А. Моделирование систем. - М.: Юрайт. - 2017. - 343 с. (С. 188-195). - ISBN: 978-5-99163916-3.

11. Маслак А.А., Макарова Е.В., Самуйленко А.Я., Сергиенко А.И. Компьютерные системы биотехнологических исследований. - М.: ВНИиТИБП. - 1993. - 432 с. (С. 127-129).

12. Салаватулина Р.М., Аюбченко В.И. Использование растительных белков в колбасном производстве. - М.: ЦНИИТЭИ мясомолпром СССР. $-1982 .-27$ с.

13. Любченко В.И. Разработка технологии вареных колбас с применением соевого изолята. Автореферат канА. диссертации. - М.: ВНИИМП. $-1983 .-25$ с.
11. Maslak A.A., Makarova E.V., Samyilenko A.Ya., Sergienko A.I. Computer systems of biotechnological investigations. - M.: VNIITIBP. - 1993. - 432 pages. (PP. 127-129).

12. Salavatulina R.M., Lubchenko V.I. The use of plant proteins in sausage production. - M.: TSNIITEI myasomolprom of the USSR.1982. - 27 pages.

13. Lubchenko V.I. Development of the technology of cooked sausages with the use of soya isolate. Author's abstract of dissertation for the Scientific Degree of Candidate of Technical Sciences. - M.: VNIIMP. - 1983. - 25 pages.

\section{СВЕДЕНИЯ ОБ АВТОРАХ}

Принадлежность к организации

Никитина Марина Александровна - кандидат технических наук, доцент, ведущий научный сотрудник, руководитель направления Информационных технологий Центра «Экономико-аналитических исследований и информационных технологий», Федеральный научный центр пищевых систем им. В.М. Горбатова РАН 109316, г. Москва, ул. Талалихина, д. 26

Тел.: +7-495-676-92-14

E-mail: nikitinama@vniimp.ru

Захаров Александр Николаевич - кандидат технических наук, старший научный сотрудник, заместитель директора по экономическим связям и маркетингу, Федеральный научный центр пищевых систем им. В.М. Горбатова РАН

109316, г. Москва, ул. Талалихина, 26.

Тел.: +7-495-676-66-91

e-mail: azakharov@vniimp.ru

Насонова Виктория Викторовна - кандидат технических наук, ведущий научный сотрудник, руководитель направления Технологии колбас, полуфабрикатов и упаковки Отдела «Научно-прикладных и технологических разработок», Федеральный научный центр пищевых систем им. В.М. Горбатова РАН

109316, г. Москва, ул. Талалихина, 26.

Тел.: +7-495-676-61-61

e-mail:vvnasonova@gmail.com

Лисицын Андрей Борисович - академик РАН, доктор технических наук, профессор, директор, Федеральный научный центр пищевых систем им. В.М. Горбатова РАН

109316, г. Москва, ул. Талалихина, 26.

Тел.: +7-495-676-95-11

e-mail:info@vniimp.ru

\section{Критерии авторства}

Авторы в равных долях имеют отношение к написанию рукописи и одинаково несут ответственность за плагиат.

Конфликт интересов

Авторы заявляют об отсутствии конфликта интересов.

Поступила 25.08.2017

\section{AUTHOR INFORMATION}

Affiliation

Nikitina Marina Aleksandrovna - candidate of technical sciences, docent, leading scientific worker, the Head of the Direction of Information Technologies of the Center of Economic and Analytical Research and Information Technologies, V.M. Gorbatov Federal Research Center for Food Systems of Russian Academy of Sciences

109316, Moscow, Talalikhinastr., 26

Tel.: +7-495-676-92-14

e-mail: nikitinama@vniimp.ru

Zakharov Aleksandr Nikolaevich - candidate of technical sciences, senior scientific worker, deputy director for economic relations and marketing, V.M. Gorbatov Federal Research Center for Food Systems of Russian Academy of Sciences

109316, Moscow, Talalikhina str., 26

Tel.: +7-495-676-66-91

e-mail: azakharov@vniimp.ru

Nasonova Victoria Victorovna - candidate of technical sciences, leading scientific worker, the Head of the Direction of Technology of Sausage Products, Semi-Finished Products and Packaging of the Department of Scientific Applied and Technological Developments, V.M. Gorbatov Federal Research Center for Food Systems of Russian Academy of Sciences

109316, Moscow, Talalikhinastr., 26

Tel.: +7-495-676-61-61

e-mail: vvnasonova@gmail.com

Lisitsyn Andrey Borisovich - doctor of technical sciences, professor, academician of the Russian Academy of Sciences, director, V.M. Gorbatov Federal Research Center for Food Systems of Russian Academy of Sciences

109316, Moscow, Talalikhina str., 26

Tel.: +7-495-676-95-11

e-mail: info@vniimp.ru

\section{Contribution}

The authors equally contributed to the writing of the manuscript and are equally responsible for plagiarism.

Conflict of interest

The authors declare no conflict of interest.

Received 25.08.2017 